\title{
ПРОБЛЕМЫ ПЕРЕВОДА ПОЛИТИЧЕСКИХ РЕЧЕЙ СИ ЦЗИНЬПИНА И СИНТАКСИЧЕСКИЕ ОСОБЕННОСТИ ИСПОЛЬЗОВАНИЯ ФРАЗЕОЛОГИЧЕСКИХ ОБОРОТОВ НА ПРИМЕРЕ ЧЭНЪЮЯ ТРАДИЦИИ ИЦЗИНА
}

\section{PROBLEMS OF TRANSLATION XI JINPING'S POLITICAL SPEECHES AND SYNTACTIC FEATURES OF USING CHENGYU OF I CHING TRADITION}

V. Kruglov

Summary: The article deals with the issues of adequate and equivalent translation of political speeches of Chinese President Xi Jinping, precisely the fragments with the phraseological expression «consistently, steadily». The source of the research is the two-volume official publication «Xi Jinping. The Governance of China». The author gives extended translation commentaries, where special attention is paid to the interpretation of chengyu from the I Ching tradition. The closest context of chengyu was also glossed, its syntactic function and meaning deformation were explained in detail, as a result it was possible to determine the peculiarities of syntactic roles of phraseological expressions in modern socio-political discourse. The structure of the analysis proposed by the author seems to be of significance in both theoretical and practical dimensions.

Keywords: Chinese language, socio-political discourse, chengyu, translation analysis, syntactic features of the use of phraseological expressions.

\author{
Круглов Владислав Владиславович \\ Соискатель, Институт стран Азии и Африки \\ Московского государственного университета \\ имени М.В. Ломоносова \\ cpp.chindep@yandex.ru
}

Аннотация: В статье рассматриваются вопросы адекватного и эквивалентного перевода политических речей Председателя КНР Си Цзиньпина на основе фрагментов официального двухтомного издания «Си Цзиньпин «0 государственном управлении», где используется фразеологический оборот «последовательно, неуклонно», произошедший из традиции Ицзина. Автор дает расширенные переводческие комментарии, где особое внимание уделено передаче на русском языке чэнъюев из комментариев Канона Перемен. Также глоссируется ближайший контекст чэнъюя, подробно объясняется его синтаксическая функция и деформация его смысла, в результате чего определяются закономерности синтаксических ролей фразеологических оборотов в современном общественно-политическом дискурсе. Методика, предлагаемая автором, может представить интерес в теоретическом, так и в практическом измерениях.

Ключевые слова: китайский язык, общественно-политический дискурс, чэнъюй, переводческий анализ, синтаксические особенности использования фразеологизмов.
$\mathrm{H}$ а фоне стремительного развития российско-китайских отношений культура Поднебесной становится все более осязаемой для российского народа. Гуманитарное сотрудничество расширяется быстрыми темпами: проводится все больше мероприятий, нацеленных на знакомство с китайской культурой, переводятся многие произведения традиционной и современной китайской литературы, число изучающих китайский язык непрерывно растет. Однако важными остаются вопросы качества трансляции китайской культуры, в том числе и политической.

Переведенное на русский язык двухтомное издание политических речей Си Цзиньпина содержит немало переводческих неточностей, особенно при интерпретации фразеологических оборотов чэнъюй. В данном исследовании проведен анализ употребления фразеологиз- мов в общественно-политическом дискурсе на примере речей Председателя КНР Си Цзиньпина и оценку адекватности официального перевода, представленного в источнике [1]. Общая стратегия анализа предполагает глоссированный фразеологический оборот с порядковым номером (№) - порядковый номер фразеологизма и речи, в которой он встречается, а также номер тома «Си Цзиньпин о государственном управлении» по схеме (№ фразеологизма. № речи) \{№ тома\} - название речи на китайском языке - авторский перевод названия речи на русский язык - фрагмент оригинального текста речи с выделенным жирным шрифтом фразеологическим оборотом из традиции Ицзина и подчеркнутым ближайшим контекстом чэнъюя (все фрагменты текста размечаны по принципы ${ }^{1}$ - номер предложения, ${ }^{\text {a }}$ - обозначение фрагмента, как правило, отделенного обычной или каплевидной запятой ${ }^{1}$ ) - официальный перевод фрагмента

Каплевидная запятая в современном китайском языке служит маркером синтаксической однородности, характеризующейся функциональной общностью элементов. 
из источника с сохранением орфографии и пунктуации с разметкой соответствия китайскому тексту - переводческий комментарий с замечаниями относительно анализа адекватности и эквивалентности перевода, в котором особое внимание уделяется передаче смысла фразеологического оборота из традиции Ицзина. В некоторых случаях предлагается полностью исправленный вариант официального перевода с соответствующей разметкой. После этой части следует синтаксический комментарий (СК) с глоссированием ближайшего контекста чэнъюя и последующим объяснением синтаксической функции фразеологического оборота и фиксированием деформации смысла.

Для рассматриваемого фразеологизма 持之以恒 и его ближайших контекстов в конце приводится пословное глоссирование, в котором намеренно не предлагается окончательный вариант перевода, который есть в переводческих комментариях, поскольку в каждом контексте конкретный фразеологизм переводится по-разному. Собственно глосса фразеологизма выглядит так:

$\begin{array}{llll}\text { 持 } & \text { 之 } & \text { 以 } & \text { 恒 } \\ \text { chí } & \text { zhī } & \text { yǐ } & \text { héng }\end{array}$

\section{держаться это INSTR. постоянный}

последовательно; упорно; постоянно; неуклонно В работе используются следующие обозначения:

RES - результативные морфемы

LOC - пространственные предлоги

NEG - показатель отрицания

ВА - маркер вынесения объекта в позицию перед глаголом

ATR - маркер определения к существительному или к глаголу

INSTR - инструмент

(1.1) $\{1\}$

Название речи: «提高党的领导水平，依靠学习走向未 来» 'Повышать уровень подготовки партийных кадров, благодаря учёбе идти к светлому будущему'.

Оригинальный текст: ${ }^{1 a}$ 群众说，16现在，18有的干部 学风不浓、1玩风太盛。2a这样26“以其昏昏， ${ }^{2 в}$ 使人昭昭"2r 是不行的！3a是要贻误工作、36贻误大事的！ 4 a不注意学 习，46忙于事务，48思想就容易僵化、4 4 庸俗化。 ${ }^{5 a}$ 学习需 要沉下心来，56贵在持之以恒，互重在学懂弄通，5r不能 心浮气躁、5 5 浅尝轩止、5 0 不求甚解。6 0 领导干部一定要 把学习放在很重要的位置上， ${ }^{66}$ 如饥似渴地学习， ${ }^{60}$ 哪怕 一天挤出半小时，6r即使读几页书，64只要坚持下去，6e 必定会积少成多、6 6 积沙成塔，63积跬步以至千里。 [2].

Официальный перевод: “`а массах поговаривают, ${ }^{16}$ что теперь ${ }^{1 в}$ у некоторых кадров нет сильного желания учиться, "га есть большое увлечение забавами. ${ }^{2 \mathrm{a}-6}$ «Коли сам блуждаешь, ${ }^{2 в}$ и приведешь других в заблуждение», потемках, то и других не просвети 2гэтого никак нельзя

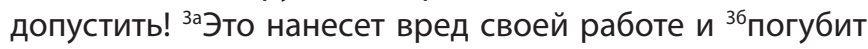

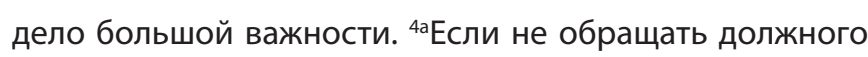
внимания и ${ }^{46}$ целый день заниматься хлопотами, ${ }^{48}$ то легко попасться в состояние закостенения закостенелости и ${ }^{4}$ пошлости. ${ }^{5 а Д л я ~ у ч е ̈ б ы ~ н а д о ~ д е р ж а т ь ~ с е б я ~ в ~ р у к а х ~}, \stackrel{56}{\underline{0}} \underline{-}$ чень ценное умение - учиться последовательно; ${ }^{5 в}$ важно по-настоящему научиться и разобраться в том, чему учиться. ${ }^{5 г Н е л ь з я ~ у ч и т ь с я ~ н е в н и м а т е л ь н о ~ и ~ в с п ы л ь ч и в о, ~}$ ${ }^{5}$ нельзя только скользить по верхам и ${ }^{5 е}$ не углубляться в существо. баРуководящие кадры должны поставить учёбу на очень важное место, ${ }^{66}$ надо стремиться к знаниям также, как нуждается в хлебе и воде. ${ }^{6}$ Пусть найдется только полчаса в день для учёбы, бгпусть читаешь только несколько страниц, ${ }^{6 д е с л и ~ д е л а т ь ~ э т о ~ п о с т о я н н о, ~}$ ${ }^{6 е}$ то из малого накопится большое, ${ }^{6 ж}$ из песка получится башня, ${ }^{63}$ маленькими шажками можно пройти и тысячу ли.» $[1$, с. 544].

Переводческий комментарий: фразу '1a' естественнее было бы перевести «в народе говорят». Слово «干 部》 ганьбу во фразе '1в' лучше перевести как «чиновник» или «должностное лицо». Конструкцию '1в-1 $r^{\prime}$ «学风不 浓、玩风太盛》 xuéfēng bù nóng, wán fēng tài shèng (учиться - стиль - NEG. - обильный, играть - стиль - чрезмерно - полный), построенную по принципу параллелизма, лучше перевести «не хотят должным образом учиться, а только желают праздно проводить время» для того, чтобы сохранить параллелизм. В переводе фраза '2a' опущена, ее лучше передать «таким образом». Фразу '26-2в' можно перевести как «возникает ситуация когда слепой ведет слепого» или «если сам заблудился, то и других не просветишь». Выражение '2r' лучше передать как «абсолютно недопустимо», а не «никак нельзя допустить». Слово 《事务》 ши'у во фразе '46' лучше перевести как «текущие дела». В переводе фразы '4а' пропущено слово «учебе». Фразу '4в-г' лучше перевести как «мышление легко становится косным и деградирует». Фразу '5а' лучше передать как «для учёбы требуется концентрация». Параллельное выражение'56-в' следовало бы перевести как «ценно - учиться последовательно, важно - хорошо разбираться в том, что изучаешь». Ряд '5г-е' удобнее перевести как «легкомысленно и поверхностно», так как данные фразы, построенные по принципам классического языка вэньянь, отчасти повторяют значения друг друга. Фразу '6б' лучше перевести как «испытывать такую же потребность в учебе, как в еде и воде». Фразу 'бв' лучше перевести как «даже если найти для учебы полчаса в день». Синтагмы '6е-з' стоит перевести как «шаг за шагом можно добиться очень многого», так как используемые фразеологизмы имеют схожее значение, что наблюдалось ранее в '5г-е'.

\section{(1.2) $\{1\}$}

Название речи: 《加强与发展中国家团结合作 弘扬丝 路精神，深化中阿合作》'Укреплять единство и углублять сотрудничество с развивающимися странами. Развивать 
дух Шёлкового пути, углублять сотрудничество Китая с арабскими странами'.

Оригинальный текст: 1а中阿共建“一带一路”， 16应 该坚持共商、1 ${ }^{1 \mathrm{~B}}$ 共建、 ${ }^{1}$ 共享原则。2a共商，26就是集思 广益，28好事大家商量着办，2r使“一带一路”建设兼顾双 方利益和关切，2呠现双方智慧和创意。3a共建，36就是 各施所长，3в各尽所能，3r把双方优势和潜能充分发挥出 来，3聚沙成塔，3e积水成渊，3\%持之以恒加以推进。4a共 享， ${ }^{46}$ 就是让建设成果更多更公平惠及中阿人民， ${ }^{48}$ 打造 中阿利益共同体和命运共同体。»[2].

Официальный перевод: “1а В совместном создании «Экономического пояса Шёлкового пути и Морского Шёлкового пути XXI века» Китай и арабские страны ${ }^{16}$ должны отстаивать принципы совместных консультаций, ${ }^{18}$ совместного строительства и ${ }^{1 г}$ совместного использования. 2аПринцип совместных консультаций ${ }^{26}$ Означает, что нуж-

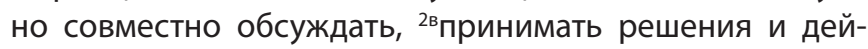

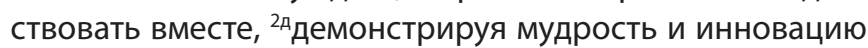
обеих сторон, 2гчтобы в процессе строительства «Экономического пояса Шёлкового пути и Морского Шёлкового пути XXI века» учитывались интересы и озабоченность всех соответствующих сторон. ${ }^{3 а}$ Совместное строительство ${ }^{36}$ Означает, что страны должны приложить все усилия ${ }^{3 в}$ и продемонстрировать все свои сильные стороны, згчтобы их преимущества и потенциальные способности полностью выявились, ${ }^{3 д п о д о б н о ~ т о м у, ~ ч т о ~ н а к о п и т ь ~ п е-~}$ ски для пагоды, ${ }^{3 е}$ накопить воды для озера, ${ }^{3 *}$ продвигая его из года и год. ${ }^{4 a}$ Совместное использование ${ }^{46}$ означает, что все народы должны на началах справедливости и равноправия пользоваться плодами строительства,

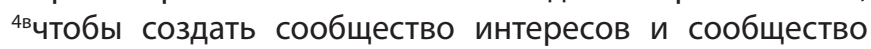
судьбы китайского и арабских народов.» [1, с. 429].

Переводческий комментарий: Слово '1в' лучше перевести «[в деле] совместного строительства». Словосочетание 《坚持原则》 изяньчи юаньцзэ во фразе '16-г' лучше переводить как «твердо придерживаться принципов». Фразу '2в' лучше перевести как «обсуждать и совершать благие дела», а вторую часть выражения '2 $r^{\prime}$ как «учитывать интересы и нужды обеих сторон». Более удачным переводом фразы'3г'представляется «в полной мере использовать преимущества и реализовать свой потенциал». Близкие по значению фразы 'Зд-е' лучше перевести одним выражением, например, «шаг за шагом идти к своей цели», а следующую за этим фразу '3ж', в которой есть рассматриваемый нами чэнъюй, лучше передать как «год за годом (неуклонно) продвигая её вперед». Политический термин 《命运共同体》 минъюнь гунтунти во фразе '4в' лучше передать как «сообщество единой судьбы».

(1.3) $\{1\}$

Название речи: 《建设社会主义文化强国 青年要自觉
践行社会主义核心价值观》 “Создание сильного социалистического государства. Молодежь должна осознанно претворять в жизнь основные социалистические ценности'.

Оригинальный текст: ${ }^{19}$ 富强、 ${ }^{16}$ 民主、 ${ }^{18}$ 文明、1「和 谐，1咱由、1 1 平等、1 1 公正、13法治，1 4 爱国、1 1 敬业、1 诚信、1 $\mathrm{m}$ 友善，1 1 传承着中国优秀传统文化的基因，10寄 托着近代以来中国人民上下求索、1n历经干辛万苦确立的 理想和信念，1p也承载着我们每个人的美好愿景。2a我们 要在全社会牢固树立社会主义核心价值观，26全体人民一 起努力， ${ }^{2 B}$ 通过持之以恒的奋斗，2把我们的国家建设得 更加富强、2 ${ }^{2}$ 更加民主、2e更加文明、2 2 更加和谐、 ${ }^{23}$ 更加 美丽， ${ }^{2 n}$ 让中华民族以更加自信、 ${ }^{2}$ 更加自强的姿态屹立 于世界民族之林。[2].

Официальный перевод: «1аБогатство, могу-

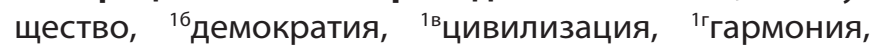

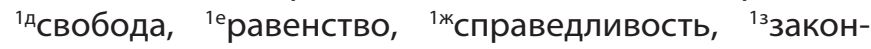

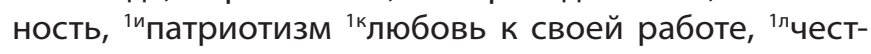
ность и 1мдружелюбие ${ }^{1 н}$ наследуют гены лучшей традиционной культуры Китая, ${ }^{10}$ воплощают в себе идеалы и убеждения, установленные китайским народом со времени новой эпохи ${ }^{1 п}$ в ходе неустанных поисков и бесчисленных невзгод и лишений, 1ра также представляют собой пре-

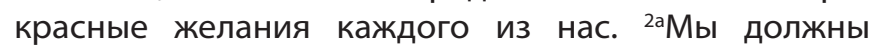
закрепить концепцию основных ценностей социализма во всем обществе, ${ }^{26}$ весь народ должен прилагать совместные усилия для того, чтобы ${ }^{2 в}$ в результате упорной борьбы ${ }^{2 г}$ сделать нашу страну еще более богатой и могущественной, ${ }^{2 д б о л е е ~ д е м о к р а т и ч е с к о и ̆, ~}$ 2еболее цивилизованной, ${ }^{2 ж б о л е е ~ г а р м о н и ч н о и ̆ ~ и ~}{ }^{23} б о-$ лее прекрасной, ${ }^{2{ }_{4}}$ тобы китайская нация более уве-

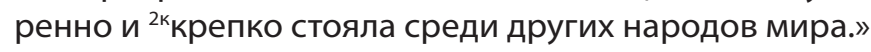
$[1$, c. 231]

Переводческий комментарий: Слово '1а' лучше переводить на русский язык: «богатство и сила [государства]», добавив союз «и». Слово '13' лучше передать как «верховенство закона». Альтернативой переводу «цивилизация» для слова '1в' может стать слово «цивилизованность». Перевод части предложения '1и-р' во многом представляется неточным: её лучше перевести с применением метода членения предложения: «[это] лучшее наследие традиционной культуры Китая, которое передаётся из поколения в поколении. В его основе лежат идеалы и убеждения, к которым китайский народ стремился со времён новой эпохи и которые прочно утвердились в ходе бесчисленных невзгод и лишений. Они опираются на лучшие представления о будущем каждого из нас». Синтагму 《社会主义核心价值观》 шэхуэйчжуи хэсинь изячжигуань во фразе '2a' лучше перевести как «систему основных социалистических ценностей». Рассматриваемый нами чэнъюй в официальном переводе передан верно. 
(1.4) $\{2\}$

Название речи: 《不忘初心，继续前进》"Помня о первоначальной цели, продолжать двигаться вперед'.

Оригинальный текст: “1a己不正，16焉能正人。” 2а 我们要从中央政治局常委会、 ${ }^{26}$ 中央政治局、 ${ }^{28}$ 中央委 员会抓起，2r从高级干部抓起，2持之以恒加强作风建 设，2e坚持和发扬党的优良传统和作风，2坚持抓常、23 抓细、2咑长，2k使党的作风全面好起来，2n确保党始终 同人民同呼吸、 ${ }^{2 m}$ 共命运、 ${ }^{2 H}$ 心连心。 ${ }^{3 a}$ 我们党作为执政 党。[2].

Официальный перевод: «1а Если сам кривой, ${ }^{16}$ то куда тебе выправлять других». ${ }^{2 a 1}$ Мы ${ }^{2 n}$ должны неуклонно и постоянно работать над партийным стилем, 2агберясь, в первую очередь, за Постоянный комитет Политбюро ЦК, ${ }^{26}$ за Политбюро и ${ }^{28} 3 а$ ЦК в целом, ${ }^{2}$ за всех ответственных партийных работников, ${ }^{2 е}$ следуя лучшим традициям и традиционному стилю нашей партии и развивая их. ${ }^{2 *} Э т а$ работа должна быть постоянной, ${ }^{23}$ долговременной и ${ }^{2 n} \mathrm{c}$ -

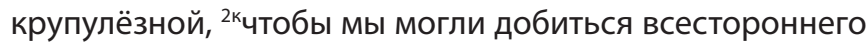

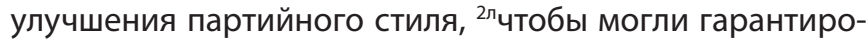
вать, что наша партия ${ }^{2 м б у д е т ~ ж и т ь ~ о д н о и ̆ ~ с у д ь б о и ̆ ~ с ~ н а-~}$ родом, будет дышать с ним одним воздухом и ${ }^{2 н}$ слышать биение его сердца. ${ }^{2}$ [1, с. 58].

Переводческий комментарий: Фразу '1а-б' лучше перевести как «Трудно требовать порядочности от других, когда самому ее не хватает». Следующий фрагмент '2а-н' следовало бы перевести как: «аначиная с Посто-

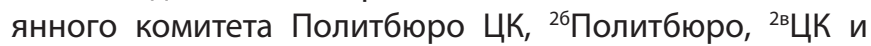
2гвысокопоставленных кадровых работников, ${ }^{2 д}$ мы все должны неуклонно выстраивать стиль работы партии, ${ }^{2 е}$ отстаивать и развивать ее лучшие традиции и стиль работы, 2жтакой вид деятельности должен проводиться на постоянной основе, ${ }^{23} \mathrm{c}$ особой тщательностью $и{ }^{2{ }^{2 n}} \mathrm{C}$ далеко идущими планами, ${ }^{2 k}$ чтобы добиться всесторон-

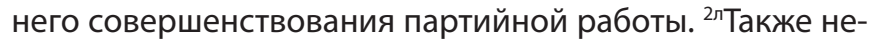
обходимо убедиться в том, что партия и народ - 2м-нэто единое целое, объединенное общей судьбой». Так как предложение 'За' вообще не было переведено, его необходимо вставить в текст в следующем виде: «Именно поэтому наша партия является правящей».

(1.5) $\{2\}$

Название речи: 《坚定不移推进党风廉政建设和反腐 败斗争》 'Твёрдо стоять на пути создания некоррумпированного правительства и партии и борьбы с коррупцией'.

Китайский текст: «192016年党风廉政建设和反腐败 工作的总体要求是 : ${ }^{16}$ 全面贯彻党的十八大和十八届三 中、 ${ }^{1}$ 四中、" ${ }^{2}$ 五中全会精神，“叶协调推进“四个全面”战 略布局，1e保持坚强政治定力，1 1 坚持全面从严治党、13 依规治党，1忠诚履行党章赋予的职责，1聚焦监督执纪 问责，1几深化标本兼治，1m创新体制机制，1 H健全法规制 度，10强化党内监督，1n把纪律挺在前面，1p持之以恒落 实中央八项规定精神，"着力解决群众身边的不正之风和 腐败问题，17坚决遏制腐败蔓延势头，1y建设忠诚干净担 当的纪检监察队伍， 19 不断取得党风廉政建设和反腐败 斗争新成效。》 [2].

Официальный перевод: «адля работы в области борьбы с коррупцией, улучшение партийного стиля и создания честного правительства в 2016 г. были выдвинуты следующие требования: ${ }^{16}$ всесторонне и последовательно претворять в жизнь идеи 18 съезда партии, а также 3-го, ${ }^{18} 4$-го и ${ }^{115}$-го пленумов ЦК КПК 18-го созыва; ${ }^{1}$ Скоординировано продвигать стратегическую концепцию «четырёх всесторонних аспектов»; ${ }^{1 е}$ поддерживать решительный политический настрой, 1жа также твёрдо проводить всестороннее устрожение

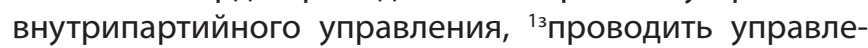
ние партией согласно правилам, '"преданно исполнять обязанности, записанные в Уставе партии; 'кделать акцент на осуществлении контроля, ${ }^{1 л п р и м е н е н и и ~ д и с-~}$ циплинарных мер и привлечении нарушителей к ответственности, стремиться лечить и симптомы, и причины «заболеваний», "мобновлять механизмы и институты, 1"оптимизировать систему правопорядка, ${ }^{10}$ усиливать внутрипартийный контроль; ${ }^{1 п}$ ставить дисциплину на первое место; ${ }^{1 p}$ последовательно претворять в жизнь дух «восьми установок», выдвинутых ЦК партий: "'делать все возможное для решения проблем коррупции и вредных поветрий, непосредственно касающихся народных масс; "'решительно сдерживать тенденцию к распространению коррупционных явлений; ${ }^{1 у}$ создать верную честную команду по проверке дисциплины и контролю, который не боится брать на себя ответственность, 1фа также постоянно достигать новых результатов антикоррупционной борьбы, создании честного правительства и улучшения стиля работы партии. $[1$, c. 227-228].

Переводческий комментарий: Часть предложения '1а' лучше перевести как «В 2016 г. для работы по созданию некоррумпированного правительства и партии и противодействию коррупции были выдвинуты следующие общие требования:». Здесь в оригинальном переводе опущены слова «总体要求》 изунти яоцю - «общие требования». Фраза '16-г' лучше передать на русском языке как «полностью претворить в жизнь идеи...». В части предложения '1д' стоит изменить «скоординировано продвигать стратегическую концепцию «четырёх всесторонних аспектов» на «скоординировано продвигать общую стратегию «четырёх всесторонних аспектов». Здесь в зависимости от целевой аудитории можно

2 Зав официальном переводе отсутствует. 
расписать саму концепцию в примечании переводчика: «стратегию «четырех всесторонних аспектов», которая включает в себя: стратегический план полного построения среднезажиточного общества, всестороннего углубления реформ, полного обеспечения законности в госуправлении и строгого осуществления внутрипартийного управления». Для фразы '1е' более удачным переводом представляется «поддерживать политическую решительность на высоком уровне». В этой фразе слово 《定力» динли употреблено как существительное, а в переводе дано как определение, что в данном контексте не оправдано. Для фразы '1ж-з' предлагаем следующий перевод: «твёрдо придерживаться полного осуществления строгого внутрипартийного управления в соответствии с уставным порядком». В ней два употребления слова «治党》 чжидан «упорядочивание партии» отделены каплевидной запятой; значит, это однородные члены, поэтому в отличие от официального перевода можно объединить все в одно предложение. Фразу '1 и' стоит перевести как «добросовестно исполнять обязанности, записанные в Уставе партии», поскольку в официальном переводе непонятно, кому нужно быть преданным, чтобы исполнять обязанности. Фрагмент '1 к-п'было бы лучше перевести как «"1куделять внимание надзору за соблюдением дисциплины и подотчётности, 1лусиливать меры по исправлению причин и следствий возможных нарушений, 1мвнедрять инновационные

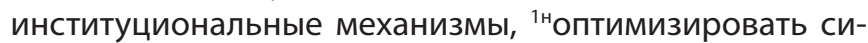
стему правопорядка, ${ }^{10}$ усиливать внутрипартийный контроль, " циплинарными требованиями в своей деятельности». Здесь стоит отказаться от слова «болезни», потому что в данном контексте речь идёт о превентивном устранении возникающих проблем в случае нарушения партийного устава или при несоблюдении дисциплины. Фразу '1р' с рассматриваемым фразеологическим оборотом предлагаем переводить как «неизменно придерживаться идеи осуществления «Правила восьми пунктов» ЦК КПК», чтобы сохранить конструкцию, аналогичную первой части текста. Фрагмент'1с' адекватнее перевести как «прилагать все усилия для искоренения нездоровых тенденций в массах и коррупции». Фразу '1т' лучше передать как «решительно подавлять распространение коррупции», поскольку в предлагаемом нами переводе уже была обозначена эта тенденция, а в оригинале она повторяется ещё раз. Следующую часть '1у' лучше передать на русский язык как «создать верные партии отряды, которые будут справедливо осуществлять дисциплинарный надзор». 《担当» даньдан в данном контексте это «берущие на себя обязанности по дисциплинарному надзору», поэтому стоит отказаться от формулировки оригинала «которые не боятся брать на себя ответственность». Для фразы '1 $\phi$ ' предлагается перевод: «непрерывно добиваться новых успехов в создании некоррумпированных правительства и партии и в противодействии коррупции».
(1.6) $\{2\}$

Название речи: 《坚持党的领导、加强党的建设是国 有企业的独特优势》 ‘Твёрдая приверженность партийному руководству и укрепление партийного строительства - исключительные преимущества государственных предприятий'.

Оригинальный текст: «a国有企业党委 ( 党组 ) 要履 行主体责任。2a要加强国有企业党风廉政建设和反腐败工 作， ${ }^{26}$ 把纪律和规矩挺在前面， ${ }^{2}$ 持之以恒落实中央八项 规定精神抓好巡视发现问题的整改变严肃查处侵吞国有 资产、2「利益输送等问题。》[2].

Официальный перевод: «аПартийные комитеты (партгруппы) должны взять на себя основную ответственность. ${ }^{2 а} \mathrm{~B}$ государственных предприятиях нужно усилить работу по созданию неподкупного управляющего аппарата, вести борьбу против коррупции, ${ }^{26}$ выдвинуть дисциплину и порядок на передний план, ${ }^{281} \underline{\text { не- }}$ уклонно внедрять в жизнь идею «восьми установок», разработанных ЦК КПК, сосредоточиться на решении проблем, выявленных в ходе инспекций, серьезно расследовать присвоение госимущества, ${ }^{2 г}$ перенаправление прибыли и прочие нарушения и ${ }^{2 в 2}$ сурово карать за них.» $[1$, с. 248].

\section{Переводческий комментарий:}

Перевод первого предложения требует корректировки, поскольку в нём упущено словосочетание «государственные предприятия» (国有企业 гою ци'е): «Партийные комитеты (партийные группы) государственных предприятий должны взять на себя главную ответственность». Далее можно сохранить официальный вариант перевода, исправив неточности и добавив упущенные

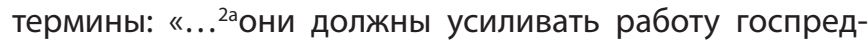
приятий по созданию некоррумпированного правительства и партии, противодействию коррупции, ${ }^{26}$ руководствоваться в своей деятельности в первую очередь дисциплинарными требованиями и нормами, ${ }^{2 в 1}$ неизменно придерживаться идеи осуществления «Правила восьми пунктов» ЦК КПК, сосредоточиться на решении проблем, выявленных в ходе инспекций, серьезно расследовать случаи присвоения госимущества и ${ }^{2 г}$ перенаправления прибыли ${ }^{282}$ и наказывать за них по всей строгости».

\section{(1.7) $\{2\}$}

Название речи: «严肃党内政治生活》'Устрожение внутрипартийной политической жизни'.

Оригинальный текст: «19理想信念， ${ }^{16}$ 源自坚守， ${ }^{1 в}$ 成于磨砺。2a要坚持不解强化理论武装， 26 毫不放松加 强党性教育，28持之以恒加强道德教育，2r教育引导广大 
党员、 2 中干部筑牢信仰之基、2e补足精神之钙、2 2 把稳思 想之舵，23坚守真理、2n坚守正道、2k坚守原则、2 2 坚守 规矩， ${ }^{2}$ 明大德、 ${ }^{2 H}$ 严公德、20守私德， ${ }^{2}$ 重品行、 ${ }^{2 p}$ 正操 守、 ${ }^{2 c}$ 养心性， ${ }^{2 T}$ 做到以信念、 ${ }^{2 y}$ 人格、 ${ }^{2 \phi}$ 实干立身。 $》[2]$.

Официальный перевод: “ㅁдеалы и убеждения ${ }^{16}$ берут начало в стойкости и ${ }^{18}$ утверждаются в ходе закалки. ${ }^{2 а}$ Надо настойчиво усиливать теоретическую вооружённость, ${ }^{26}$ неослабно углублять воспитание в духе партийности, ${ }^{2 в}$ последовательно проводить нравственное воспитание, ${ }^{2 г}$ обучать и направлять широкие массы членов партии и ${ }^{2 д}$ кадровых работников на укрепление фундамента веры, ${ }^{2 е}$ с тем чтобы восполнять недостаток духовного кальция в организме, ${ }^{2 *}$ твёрдо держаться за

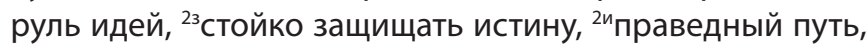

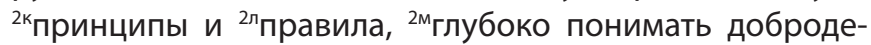

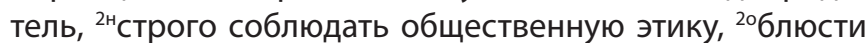
личную мораль, ${ }^{2 п}$ следить за своими поступками, ${ }^{2 p}$ сохранять нравственную чистоту, ${ }^{2 c}$ культивировать в себе порядочность, ${ }^{2 т}$ стремиться найти своё место в жизни ${ }^{2 т}$ с помощью твёрдых убеждений, ${ }^{2 y}$ личных качеств и ${ }^{2 \phi}$ практических действий.» [1, с. 256].

Переводческий комментарий: Предложение '1ав' лучше перевести как: «Идеалы и убеждения возникают благодаря стойкости человека и окончательно формируются в результате его работы над собой». На наш взгляд, адекватным переводом синтагмы '2a' представляется «Мы должны неуклонно укреплять теоретическую подкованность людей», поскольку слово «вооружённость» официального перевода звучит слишком буквально. В переводе фразы '26' на русский язык стоит заменить «воспитание в духе партийности» на «непрестанное укрепление системы партийного просвещения». Синтагму '2в' с рассматриваемым чэнъюем при переводе можно объединить с предыдущей, поскольку они близки по строению и смыслу: «непрестанно улучшать систему партийного просвещения и нравственное воспитание». Далее часть '2г-ж' содержит сходные грамматические конструкции, поэтому переводить её стоит как единое целое: «образование должно создать для широких масс членов партии и кадровых работников прочную идейную основу, наполнить их духовной сущностью, и укрепить их идеологию». Ряд четырехслогов '2з-л' адекватнее перевести как: «²3необходимо твёрдо

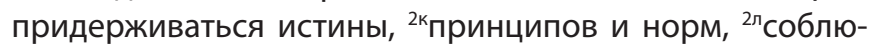
дать дисциплину». В следующей части '2м-о' также используется одна и та же конструкция, и переводить ее

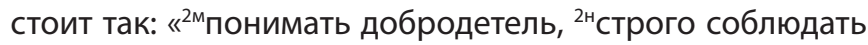
нормы общественной морали и ${ }^{20}$ развивать личные моральные качества». Следующий ряд трехслогов '2п-с' лучше перевести как: «"пследить за своим поведением, ${ }^{2 p}$ придерживаться этических принципов и ${ }^{2 c}$ воспитывать в себе порядочность». Данные две части построены по принципу морфемной контракции, поэтому при переводе нужно проследить этимологию иероглифов, что- бы передать полное значение фраз. Во фрагменте '2т- $\phi$ ' в конце стоит перевести как «найти своё место в жизни благодаря твёрдым убеждениям, личным качествам и реальным заслугам».

(1.8) $\{2\}$

Название речи: «2015年3月9日在参加第十二届全国 人民代表大会第三次会议吉林代表团审议时的讲话要点》 'Основные положения выступления на заседании делегации провинции Цзилинь на третьей сессии ВСНП двенадцатого созыва (от 09.03.2015г.)'.

Оригинальный текст: «1a民生工作离老百姓最近，16 同老百姓生活最密切。2a要持之以恒把民生工作抓好，26 发扬钉钉子精神， $2 \mathrm{~B}$ 有坚持不懈的韧劲， 2 推出的每件事都 要一抓到底，2 2 一件事情接着一件事情办，2e一年接着一 年干， 2 锲而不舍向前走， ${ }^{2} 3$ 做到件件有着落、 $2 n$ 事事有 回音, ${ }^{2}$ 让群众看到变化、2 2 得到实惠。» [2].

Официальный перевод: «аработы, проводимые для достижения народного процветания, ${ }^{16}$ очень близки простым людям и тесно связаны с их жизнью. ${ }^{2 а} \underline{\text { Нужно }}$ непрестанно вносить вклад в работу над достижением народного процветания, ${ }^{26}$ как забивая гвозди, ${ }^{2 в}$ неустанно придерживаться цели, 2гдоводить до конца каждое начатое дело, ${ }^{2 д}$ Выполнять дела одни за одним, ${ }^{2 \mathrm{e}}$ из года в год ${ }^{2}$ двигаться вперед, ${ }^{23}$ доводить все до результата, ${ }^{2 и}$ давать ответ на каждый запрос, ${ }^{2 \kappa}$ чтобы народ смог уви-

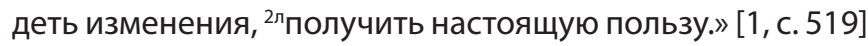

Переводческий комментарий: Вместо слова «работы» в части предложения '1а' следует использовать форму единственного числа, поскольку оно подразумевает комплекс мер в какой-либо сфере с целью достижения желаемого результата. Кроме того, в сочетании «работа близка кому-то» слово «работа» понимается как результат деятельности (литературной), например: «его работы мне близки» (в значении «идеи, содержащиеся в работах, написанных им, близки мне»). В данном контексте уместно и слово «меры». Также кажется излишним использование сочетания «простой народ»: слово «простой» имеет определенную стилистическую окраску, которая в данном тексте кажется несколько неуместной, предполагая разницу в статусе говорящего и тех, о ком он говорит. Исходя из вышесказанного, более точным будет следующий перевод данного предложения: «меры, проводимые с целью достижения народного процветания, тесно связаны с народом и его жизнью». Фразеологический оборот 《持之以恒》 чичжи'ихэн в '2a' передан верно. Сочетание «把工作抓好》 ба гунизо чжуахао во фразе '2a' стоит переводить как «(хорошо) делать свое дело», а следующую за ней фразу '26' как «брать все от каждого мгновения, тяжко трудиться ради достижения цели». Переводчик мог спутать стоящие рядом «钉》 чжэнь и « 钉子» чжэньцзы, переведя их как «забивать гвозди», од- 
нако, в отдельности, «钉》 чжэнь также имеет значения «следовать, идти за кем-то, наблюдать, внимательно смотреть», что в сочетании с глаголом «发扬》 фра'ян (продвигать, распространять, усиливать) получает значение «распространять». Также отметим, что явного сравнения в оригинальном предложении не наблюдается, следовательно, отпадает необходимость использования в переводе сравнительной конструкции с «как». Конструкция '2д-е' делится на две параллельные части: числительное (+ сч.сл.) + сущ. + 接着 изечжэ + числ. (+ сч.сл.) + сущ. + глагол (делать). Глаголы «办» бань и «干» гань имеют общее значение - «делать что-либо», следовательно, данную конструкцию можно перевести как «вести дела одно за другим, год за годом». Также разумно перевести конструкцию '2ж', имеющую в своем составе чэнъюй: « 铸而不舍》 це’эр бушэ (неустанно, упорно), как: «упорно идти вперед». Особого внимания заслуживает фраза '23и': «в любом деле необходима организация, распорядок, чтобы каждый понимал свои обязанности, ответственность. Любое дело необходимо претворять в жизнь и доводить до конца, а по окончании иметь обратную связь». «Давать ответы на вопросы» должны не говорящий и не исполнитель, а те, для кого данные мероприятия проводятся. Делается это с целью поддержания рабочего цикла: планирование - реализация - получение обратной связи - корректировка действий. Таким образом, конец отрывка стоит перевести следующим образом: «Следует постоянно принимать меры по достижению народного процветания, тяжко трудиться над достижением данной цели, неустанно быть настойчивыми, доводить до конца каждое начатое дело, вести дела одно за другим, год за годом, с упорством идти вперед, достигать результатов и иметь обратную связь, чтобы народ мог увидеть изменения и получить настоящую пользу».

\section{(1.9) $\{2\}$}

Название речи: «弘扬塞罕坝精神»'Укреплять дух лесопарка Сайханьба'.

Оригинальный текст: “"a全党全社会要坚持绿色发 展理念，16弘扬塞罕坝精神，1持之以恒推进生态文明建 设，1r一代接着一代干，1吗而不息，1e久久为功，1努力 形成人与自然和谐发展新格局，13把我们伟大的祖国建设 得更加美丽，1n为子孙后代留下天更蓝、1 ${ }^{1 k}$ 山更绿、1"水 更清的优美环境。»[2].

Официальный перевод: “`аПартии и обществу в целом надо придерживаться «зелёной» концепции развития, ${ }^{16}$ развивать дух Сайханьба, ${ }^{18}$ неизменно придерживаться поощрения экокультурного строительства, 1дупорно продолжать 'гдело предыдущих поколений, ${ }^{1 е}$ неотступно, ${ }^{1 *}$ старательно выстраивать новую стратегию мирного соразвития человека и природы. ${ }^{13} \mathrm{Mы}$ должны сделать нашу великую Родину прекраснее, 1nоставить нашим потомкам чудесную природу с синим не- бом, 1кзелёными горами и 1лчистой водой.» $[1$, с. 572]»

Переводческий комментарий: Конструкцию '1г-е' стоит перевести как: «без остановки, упорно продолжать дело предыдущих поколений», поскольку последние две части разъясняют первую, представляя собой чэнъюи. В заключительном фрагменте '1 и-л' явно видны составленные по признаку параллелизма части: сущ. + 更 гэн 'еще более' + прил., следовательно, его уместно перевести следующим образом: «1n оставить прекрасную

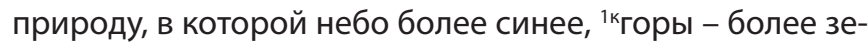
леные, 1ла вода - более чистая». В данном отрывке рассматриваемый чэнъюй передан верно.

\section{(1.10) $\{2\}$}

Название речи: «开启金砖合作第二个“金色十年》 'Открытие второго «Золотого десятилетия» БРИКС»'.

Оригинальный текст: «"a 金砖合作之所以得到快速发 展，16关键在于找准了合作之道。2a这就是互尊互助，26 携手走适合本国国情的发展道路， ${ }^{2 B}$ 秉持开放包容、2 作共赢的精神，2持之以恒推进经济、2e政治、2世人文合 作，23倡导国际公平正义，2n同其他新兴市场国家和发展 中国家和衷共济， $2 k$ 共同营造良好外部环境。»[2].

Официальный перевод: «1а Динамичное развитие сотрудничества БРИКС ${ }^{16}$ В значительной степени стало возможным благодаря тому, что мы нашли для него правильную дорогу. ${ }^{2 а}$ Вот в чем этот путь: взаимно уважать и помогать друг другу; ${ }^{26}$ сообща идти по пути, соответствующему национальным реалиям своей страны; ${ }^{2 д}$ устойчиво продвигать экономические, ${ }^{2 e}$ политические и ${ }^{2}$ культурно-гуманитарные связи ${ }^{2 \mathrm{~B}}$ В духе открытости, инклюзивности, взаимной выгоды и 2гсотрудничества; ${ }^{23}$ выступать за международное равенство и справедливость; ${ }^{2 n}$ вместе с другими странами с нарождающимися рынками и развивающимися странами ${ }^{2 \kappa}$ создавать благоприятную внешнюю обстановку.» [1, с. 705]»

Переводческий комментарий: Два первых знака фрагмента '2a' правильнее перевести как «Данный путь состоит в следующем» или «Он состоит в следующем». Рассматриваемый фразеологический оборот «持之以 恒》 чичжи ихэн также стоит перевести как «неуклонно», которое лучше сочетается со словом «продвигать». Также более корректным будет перевести синтагму «新兴市 场国家》 синьсин шичан гоцзя во фразе '2и' как «страны с развивающимися рынками».

\section{$(1.1-10 . \mathrm{CK})$}

(1.1.CK)

5a学习需要 沉下心来，56贵 在持之以恒， xuéxí xūyào chén xià xīn lái guì zài chízhīyǐhéng учиться надо сосредоточиться дорогой LOC. по- 
следовательно

${ }^{5} \mathrm{~B}$ 重 在学懂 弄通

zhòng zài xuédǒng nòngtōng

важный LOC. усвоить постичь

для учёбы требуется концентрация, ценность -в последовательности, важность - в усвоении и постижении

\section{(1.2.CK)}

3*持之以恒加以推进

chízhīyl̆héng jiāyǐ tuijìn

постоянно подвергать продвижение

неуклонно продвигая её вперед

\section{(1.3.CK)}

28 通过持之以恒的奋斗

tōngguò chízhīylhéng de fèndòu

через постоянный ATR борьба

в результате упорной борьбы

\section{(1.4.CK)}

2持之以恒加强作风建设

chízhīylhéng jiāqiáng zuòfēng jiànshè

постоянный усиливать стиль строительство

неуклонно выстраивать стиль работы партии

\section{(1.5-6.CK)}

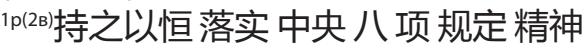

chízhīyìhéng luòshí zhōngyāng bā xiàng guīdìng jīngshén

неизменно осуществлять ЦК [КПК] 8 пункт правило дух неизменно придерживаться духа Правила восьми пунктов ЦК КПК

\section{(1.7.CK)}

28持之以恒加强 道德 教育

chízhīyihhéng jiāqiáng dàodé jiàoyù

непрестанно усиливать мораль образование

непрестанно улучшать воспитание морали

\section{(1.8.CK)}

\section{2a要 持之以恒把 民生工作抓好}

yào chízhīy̌̀héng bă mínshēng gōngzuò zhuā hăo

нужно непрестанно ВА народ-жизнь работа схва-
тить.RES

непрестанно овладевать работой на благо народного процветания

(1.9.CK)

18持之以恒推进生态文明建设

chízhīy̆héng tuījìn shēngtài wénmíng jiànshè

неизменно продвигать экология культура строительство

неизменно продвигать экокультурное строительство

\section{(1.10.CK)}

2持之以恒推进经济、 ${ }^{2 e}$ 政治、

chízhīylhéng tuījìn jīngjì zhèngzhì

неуклонно продвигать экономика политика

2ж人文合作

rénwén hézuò

гуманитарный сотрудничество

неуклонно продвигать экономическое, политическое и гуманитарное сотрудничество

Проанализированный материал показывает, что фразеологический оборот 持之以恒 чичжи ихэн закрепился в современном китайском языке как наречие; в большинстве примеров он выступал как обстоятельство образа действия и лишь в одном случае (1.3) он приобрел адъективное значение, будучи употребленным в качестве определения к существительному.

Анализ 10 фрагментов политических программных речей Си Цзиньпина, содержащих фразеологический оборот чэнъюй из традиции Ицзина, позволяет сделать вывод о том, что перевод фразеологических оборотов требует контекстуального анализа и обращения к первоисточнику, точнее к памятнику или традиции, откуда произошёл тот или иной фразеологический оборот. Было установлено, что фразеологический оборот традиции Ицзина (1) «持之以恒» получает различные интерпретации в разных контекстах. Обращение к древности и мудрости предков в исходной лингвистической форме остаётся лейтмотивом сегодняшней политической действительности, вербализованной в программных речах Председателя КНР Си Цзиньпина.

\section{ЛИТЕРАТУРА}

1. 习近平系列重要讲话数据库. - Режим доступа: http://jhsjk.people.cn/ (дата обращения: 05.03.2019) Банк данных программных речей Си Цзиньпина.

2. 习近平谈治国理政 : 俄文 / 习近平著 ; 俄文翻译组译. - 北京 : 外文出版社，2014. Си Цзиньпин «0 государственном управлении»: Издание на русском языке / автор: Си Цзиньпин; перевод на русский язык выполнен переводческой группой. - Пекин: Издательство иностранной литературы, 2014.

( Круглов Владислав Владиславович (срp.chindep@yandex.ru).

Журнал «Современная наука: актуальные проблемы теории и практики» 